\title{
Presence of accompanying head injury in patients with maxillofacial trauma
}

\author{
Maksillofasiyal travması bulunan hastalarda eşlik eden kafa travması varlığı
}

\author{
Dağhan IŞIK, ${ }^{1}$ Hayriye GÖNÜLLÜ, ${ }^{2}$ Sevdegül KARADAŞ, ${ }^{2}$ Ö. Faruk KOÇAK, ${ }^{1}$ \\ Sıddık KESKİN, ${ }^{3}$ M. Fatih GARCA, ${ }^{4}$ Metehan EŞEOĞLU $^{5}$
}

\section{BACKGROUND}

Patients with maxillofacial fractures are at high risk of accompanying traumatic cranial injuries. Prompt determination of head injury in these patients is crucial for improving patient survival and recovery.

\section{METHODS}

The records of 246 patients with maxillofacial fractures referred to the emergency department of our hospital between January 2006 and September 2009 were reviewed in this retrospective study. The patients' age and gender, cause, type and location of the maxillofacial fracture, and the cranial injuries were analyzed.

\section{RESULTS}

The mean age of the patients was $23.61 \pm 16.75$ years $(83.3 \%$ males and $16.7 \%$ females). Cranial injury was observed in 38 patients with maxillofacial trauma. While the risk of head injury was found to be 3.44-fold lower among patients with single facial bone fracture $(\mathrm{p}<0.001)$, the risk of experiencing head injury significantly increased in patients with multiple facial bone fractures $(\mathrm{p}<0.001)$. The risk of head trauma significantly increased in patients with fractures of the nasal bone, maxillary bone, mandibular bone, and with frontal region fractures ( $\mathrm{p}<0.05$ in each group).

\section{CONCLUSION}

The patients with multiple facial bone fractures should be investigated with regard to head injury even if they do not have clinical findings.

Key Words: Maxillofacial trauma; head injury; facial bone fracture.

\section{AMAC}

Maksillofasiyal kırığı bulunan hastalar, bu travmaya eşlik eden kafa travması geçirme konusunda yüksek risk altındadırlar. Bu hastalarda kafa travmasının erken anlaşılması hastanın sağkalımı ve iyileşmesi için kritik öneme sahiptir.

\section{GEREÇ VE YÖNTEM}

Ocak 2006 ile Eylül 2009 tarihleri arasında hastanemizin acil servisine maksillofasiyal kırık nedeniyle gönderilen 246 hastanın kayıtları geriye dönük olarak tarandı. Hastaların yaş, cinsiyet, maksillofasiyal travmanın nedeni, tipi, yerleşimi ve kafa travması analiz edildi.

\section{BULGULAR}

Hastaların yaşlarının ortalaması $23,61 \pm 16,75$ idi $(\% 83,3$ erkek, \%16,7 kadin). Kraniyal yaralanma maksillofasiyal travmalı 38 hastada gözlendi. Hastalar arasında tek yüz kemiği kırığg bulunanlarda kafa travması riski çoklu kırıklı hastalara göre 3,44 kat daha az gözlenirken ( $p<0,001)$, yüz kemiği çoklu kırılan hastalarda kafa travması geçirme riski anlamlı derecede artmıştı $(\mathrm{p}<0,001)$. İçinde nazal kemik, maksiller kemik, mandibular kemik ve frontal bölge kırığ bulunan hastalarda kafa travması riski önemli derecede artmiştı ( $<<0,05$ her bir grupta).

\section{SONUÇ}

Çoklu yüz kemik kırığı bulunan hastalarda klinik bulguları olmasa dahi kafa travması yönünden araştırılmaları gerekir.

Anahtar Sözcükler: Maksillofasiyal travma; kafa travması; yüz kemik kırığı.
Departments of ${ }^{1}$ Plastic and Reconstructive Surgery, ${ }^{2}$ Emergency Medicine, ${ }^{3}$ Biostatistics, ${ }^{4}$ Otorhinolaryngology, ${ }^{5}$ Neurosurgery, Yuzuncu Yil University, Faculty of Medicine, Van, Turkey.
Yüzüncü Yıl Üniversitesi Tıp Fakültesi, ${ }^{1}$ Plastik ve Rekonstrüktif Cerrahi ABD, ${ }^{2}$ Acil Tip ABD, ${ }^{3}$ Biyoistatistik ABD, ${ }^{4}$ Kulak Burun Boğaz Hastalıkları ABD, ${ }^{5}$ Nöroşirürji ABD, Van. 
Patients with maxillofacial fractures may have concomitant intracranial, pulmonary, intraabdominal, or extremity injuries. ${ }^{[1-3]} \mathrm{A}$ close relationship between maxillofacial fracture and intracranial injury has been reported in many articles. ${ }^{[3-8]}$ In many countries, cranial injury has been found to be the most common accompanying organ injury in patients with maxillofacial trauma. ${ }^{[2-5]}$ This includes head traumas, intracranial hemorrhages, closed head traumas (brain contusion or laceration), or skull fracture. Generally, the presence of emesis, vomiting, loss of consciousness, or a low Glasgow Coma Scale (GCS) score are important findings for suspicion of a cranial injury. However, in patients with maxillofacial trauma, head trauma may be seen without observing these findings suggesting head trauma. ${ }^{[8]}$ Presence of head trauma in patients with maxillofacial trauma is a life-threatening condition increasing the mortality. ${ }^{[5,7]}$ Prompt detection may lead to improved results, as early decompression of an intracranial pressure is crucial in improving the outcome in head injury patients. ${ }^{[9-11]}$ Thus, the healthcare provider who initially assesses the patient should examine the patient in terms of intracranial injury, which increases the morbidity and mortality. Although the relationship between head trauma and facial fractures classified as upper, middle and lower facial fractures has been investigated in the literature, the correlations between the fracture in each facial bone and cranial injury have not been clarified.

In this study, patients with maxillofacial traumas were reviewed retrospectively; those with cranial injury were included in a study group, and those without cranial injury were included in a control group. In this way, it was attempted to determine which facial fractures increased the risk of head injury.

\section{MATERIALS AND METHODS}

The medical records of the patients with maxillofacial fractures seen in the emergency department of Yuzuncu Yil University Turkey between January 2006 and September 2009 were reviewed. Age, sex, the season in which patients were referred to the hospital, the etiology of the trauma, the fractured bone in the face, accompanying cranial injury, GCS, and data regarding the mortality of the patients were noted. The patients were analyzed in four groups as those aged $<16$ years, $16-40$ years, $41-60$ years, and $\geq 61$ years. Maxillofacial trauma in the patients was recorded as soft tissue trauma, nasal fracture, maxillary fracture, mandibular fracture, frontal bone fracture (anterior wall of the frontal sinus and the upper orbital rim), lower orbital rim fracture, and zygomatic fracture (Fig. 1), which had been diagnosed by clinical and radiological examination. Facial injuries detected in the patients were analyzed in three categories as isolated cases (each facial bone fracture is isolated), complex cases (other facial fractures also accompanying the analyzed bone fracture), and the total of both groups. Among these patients, those who had been diagnosed radiologically with intracranial hemorrhage, cerebral contusion or skull fracture were determined. Cases with subarachnoid hemorrhage, subdural hemorrhage, epidural hemorrhage, and intracranial hemorrhage were classified as the intracranial hemorrhage group. Cases with pneumocephalus, non-displaced skull fractures and open head trauma were classified as the skull fracture group. Cases with cerebral contusion and laceration were classified as the cerebral contusion group. Afterwards, patients with maxillofacial trauma experiencing head trauma were taken as the study group, and patients with maxillofacial trauma but not suffering from head trauma were taken as the control group.

\section{Exclusion from the Study}

Patients with large soft tissue trauma were included in the soft tissue trauma group. Patients with injuries not caused by blunt trauma, but only composed of linear skin lacerations and traumas in the form of a small edematous area or demarcated hematoma were not included in this group. Of the patients with maxil-

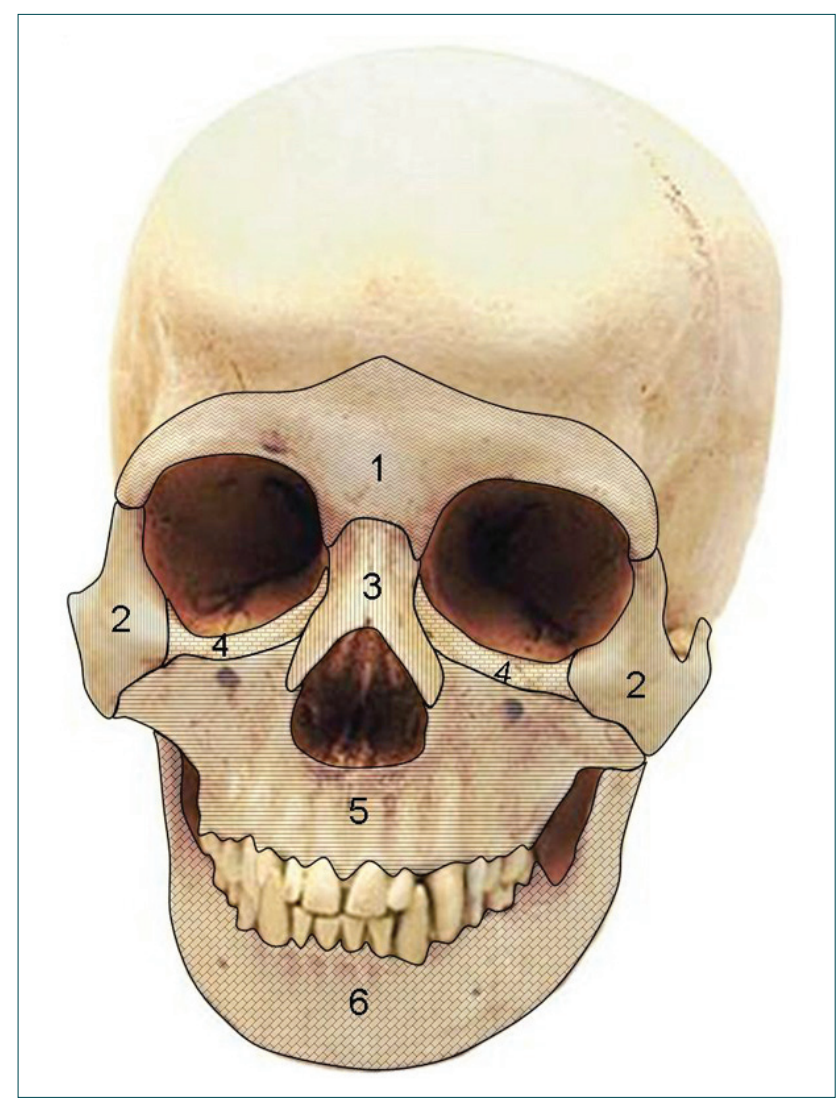

Fig. 1. Sites of diagnosed facial fractures in the patients included in the study. 1) Frontal region, 2) zygomatic region, 3) nasal region, 4) lower orbital rim, 5) maxillary region, and 6) mandibular region. (Color figures can be viewed in the online issue, which is available at www.tjtes.org). 
lofacial fractures, those who only had frontal sinus anterior wall fracture and upper orbital rim fracture were included in frontal fracture group. Patients with other frontal fractures were not included in this group.

\section{Statistical Analysis}

Descriptive statistics are presented as numbers and percentages. To test for the relationships between the study and control groups, the Pearson's chi-square test and the Fisher's exact test (when the expected counts were less than 5) were used for the categorical variables. p-values $<0.05$ were considered significant. The risks of head injury for different potential predictors were calculated by the odds ratios (OR) and 95\% confidence intervals (CI). These statistical analyses were performed using the Statistical Package for the Social Sciences (SPSS) (ver. 13) statistical program. Multiple correspondence analyses were used for the relationship between the selected groups by using Minitab (ver. 15) statistical program. Data from multiple correspondence analyses were given graphically.

\section{RESULTS}

A total of 246 patients were included in the study (study group: 38 patients, control group: 208 patients). The age and gender of the patients in both groups and the etiologies of traumas are summarized in Tables 1 and 2 .

\section{Age, Sex and Season of the Injury}

Of the 246 patients included in the study, 83.3\% $(205 / 246)$ were males and $16.7 \%(41 / 246)$ were females. While $81.6 \%$ of the patients with head injury were males, $18.4 \%$ were females. No significant difference was found between gender and experiencing head trauma. The mean age of the patients was $23.61 \pm 16.75$ years. Of all the patients, $30.1 \%$ were aged $<16$ years of age, $49.2 \% 16-40$ years, $16.2 \% 41-60$ years, and $4.5 \%$ $\geq 61$ years. These rates were $26.3 \%, 36.8 \%, 31.6 \%$, and $5.3 \%$, respectively, in patients with maxillofacial trauma experiencing head trauma (Table 1). A significant increase was detected between age and experiencing head trauma only in the 41-60 age group $(\mathrm{p}=0.005)$. While maxillofacial trauma was most commonly seen in the summer, no significant difference was found between seasons and head injury.

\section{Head Injury}

Of the patients, $15.4 \%(38 / 246)$ experienced head trauma. Of these patients, 15 experienced skull fracture, 14 contusion, and nine intracranial hemorrhage (Table 3).

Table 1. Demographic characteristics, cause and mechanism of injury in 246 patients in a univariate analysis

\begin{tabular}{|c|c|c|c|c|c|c|}
\hline & $\begin{array}{l}\text { All patients }(\%) \\
\qquad(\mathrm{n}=246)\end{array}$ & $\begin{array}{l}\text { Study group }(\%) \\
\qquad(\mathrm{n}=38)\end{array}$ & $\begin{array}{l}\text { Control group }(\%) \\
\qquad(\mathrm{n}=208)\end{array}$ & $\mathrm{p}$ & OR & $95 \% \mathrm{CI}$ \\
\hline \multicolumn{7}{|l|}{ Sex } \\
\hline Male & $205(83.3)$ & $31(81.6)$ & $174(83.7)$ & Ns & 0.86 & $0.35-2.12$ \\
\hline Female & $41(16.7)$ & $7(18.4)$ & $34(16.3)$ & Ns & 1.15 & $0.47-2.83$ \\
\hline \multicolumn{7}{|l|}{ Age } \\
\hline $0-15$ & $74(30.1)$ & $10(26.3)$ & $64(30.8)$ & Ns & 0.80 & $0.36-1.75$ \\
\hline $16-40$ & $121(49.2)$ & $14(36.8)$ & $107(51.4)$ & Ns & 0.55 & $0.27-1.12$ \\
\hline $41-60$ & $40(16.2)$ & $12(31.6)$ & $28(13.5)$ & 0.005 & 2.96 & $1.34-6.54$ \\
\hline$\geq 61$ & $11(4.5)$ & $2(5.3)$ & $9(4.3)$ & Ns & 1.22 & $0.25-5.92$ \\
\hline \multicolumn{7}{|l|}{ Season of injury } \\
\hline Summer & $104(42.3)$ & $15(39.5)$ & $89(42.8)$ & Ns & 0.87 & $0.43-1.76$ \\
\hline Autumn & $71(28.9)$ & $13(34.2)$ & $58(27.9)$ & Ns & 1.34 & $0.64-2.80$ \\
\hline Winter & $31(12.6)$ & $6(15.8)$ & $25(12.0)$ & Ns & 1.37 & $0.52-3.60$ \\
\hline Spring & $40(16.2)$ & $4(10.5)$ & $36(17.3)$ & Ns & 0.56 & $0.18-1.68$ \\
\hline \multicolumn{7}{|l|}{ Etiology of trauma } \\
\hline Gunshot & $9(3.7)$ & $1(2.6)$ & $8(3.8)$ & Ns & 0.67 & $0.08-5.56$ \\
\hline Assault & $54(22.0)$ & $6(15.9)$ & $48(23.1)$ & Ns & 0.62 & $0.24-1.58$ \\
\hline Traffic accident & $72(29.3)$ & $15(39.5)$ & $57(27.4)$ & Ns & 1.72 & $0.84-3.54$ \\
\hline In-vehicle traffic accident & $49(19.9)$ & $10(26.3)$ & $39(18.7)$ & Ns & 1.54 & $0.69-3.45$ \\
\hline Out-of-vehicle traffic accident & $23(9.4)$ & $5(13.2)$ & $18(8.7)$ & Ns & 1.59 & $0.55-4.60$ \\
\hline Accidental falls & $69(28.0)$ & $11(28.9)$ & $58(27.9)$ & Ns & 1.05 & $0.49-2.26$ \\
\hline Animal trauma & $18(7.3)$ & $1(2.6)$ & $17(8.2)$ & Ns & 0.30 & $0.03-2.35$ \\
\hline Others & $24(9.7)$ & $4(10.5)$ & $20(9.6)$ & Ns & 1.13 & $0.30-4.01$ \\
\hline \multicolumn{7}{|l|}{ Glasgow coma scale } \\
\hline $3-8$ & $7(2.8)$ & 7 (18.4) & $0(0)$ & $<0.001$ & 0.13 & $0.09-0.18$ \\
\hline $9-12$ & $19(7.7)$ & $17(44.8)$ & $2(0.1)$ & $<0.001$ & 83.3 & $18.0-385.9$ \\
\hline $13-15$ & $220(89.4)$ & $14(36.8)$ & 206 (99.9) & $<0.001$ & 0.006 & $0.001-0.02$ \\
\hline
\end{tabular}




\section{Mechanism of Injury}

Patients experienced maxillofacial trauma most frequently due to traffic accidents $(20.3 \%)$, followed by falls $(28.0 \%)$, and strikes $(22.0 \%)$. However, when the patients were analyzed in terms of trauma etiology and risk of head trauma, no causes significantly increasing the risk of head trauma were found.

\section{Injury Profile}

While the risk of head trauma decreased 3.4-fold in cases with only one facial bone fracture compared to those with multiple facial fractures $(p=0.002)$, the risk of head trauma significantly increased in multiple (2 or more) facial bone fractures $(p<0.001)$. When each facial bone was evaluated individually, no significant relationship was found between isolated fracture of the facial bones and risk of head trauma. Nevertheless, the risk of head trauma was found to increase in the presence of an accompanying facial bone fracture for each of the nasal bone, maxilla, mandible, and frontal
Table 3. Description and type of head injury in 38 patients

\begin{tabular}{lcc}
\hline Head injury & $\mathrm{n}$ & $\%$ \\
\hline Skull fracture & 15 & 6.09 \\
$\quad$ Pneumocephalus & 7 & 2.84 \\
Cranial fracture & 7 & 2.84 \\
$\quad$ Open head trauma & 1 & 0.40 \\
Contusion & 14 & 5.69 \\
Intracerebral hemorrhage & 9 & 3.65 \\
$\quad$ Epidural hemorrhage & 5 & 2.03 \\
Subarachnoid hemorrhage & 2 & 0.81 \\
Subdural hemorrhage & 1 & 0.40 \\
Intracranial hemorrhage & 1 & 0.40 \\
\hline
\end{tabular}

sinus fractures $(\mathrm{p}=0.004, \mathrm{p}=0.022, \mathrm{p}<0.001, \mathrm{p}<0.001$, respectively). When we evaluated all (isolated and complex fractures) of the patients with frontal sinus fracture, the risk of head injury was found to increase significantly $(p<0.001)$. In the multiple correspon-

Table 2. Profile of facial fractures and relationship with head injury

\begin{tabular}{|c|c|c|c|c|c|c|}
\hline & $\begin{array}{l}\text { All patients }(\%) \\
\qquad(\mathrm{n}=246)\end{array}$ & $\begin{array}{l}\text { Study group }(\%) \\
\qquad(\mathrm{n}=38)\end{array}$ & $\begin{array}{l}\text { Control group }(\%) \\
\qquad(\mathrm{n}=208)\end{array}$ & $\mathrm{p}$ & OR & $95 \% \mathrm{CI}$ \\
\hline \multicolumn{7}{|l|}{ Type of MFT } \\
\hline \multicolumn{7}{|l|}{ STT } \\
\hline Isolated & $18(7.3)$ & $1(2.6)$ & $17(8.1)$ & Ns & 0.30 & $0.03-2.35$ \\
\hline Total & $169(68.7)$ & $29(76.3)$ & $140(67.3)$ & Ns & 1.56 & $0.70-3.49$ \\
\hline \multicolumn{7}{|l|}{ Nasal fr. } \\
\hline Isolated & $24(9.7)$ & $1(2.6)$ & $23(11.1)$ & Ns & 0.21 & $0.02-1.66$ \\
\hline Complex with nasal fr. & $74(30.1)$ & $19(50.0)$ & $55(26.4)$ & 0.004 & 2.78 & $1.37-5.63$ \\
\hline Total & $98(39.8)$ & $20(52.6)$ & $78(37.5)$ & Ns & 1.85 & $0.92-3.71$ \\
\hline \multicolumn{7}{|l|}{ Maxillary fr. } \\
\hline Isolated & $33(13.4)$ & $3(7.9)$ & $30(14.4)$ & Ns & 0.50 & $0.14-1.75$ \\
\hline Complex with maxillary fr. & $89(36.2)$ & $20(52.6)$ & $69(33.1)$ & 0.022 & 2.23 & $1.11-4.50$ \\
\hline Total & $122(49.6)$ & $23(60.5)$ & $99(47.5)$ & Ns & 1.6 & $0.83-3.41$ \\
\hline \multicolumn{7}{|l|}{ Mandibular fr. } \\
\hline Isolated & $27(11.0)$ & $1(2.6)$ & $26(12.5)$ & Ns & 0.18 & $0.02-1.43$ \\
\hline Complex with mandibular fr. & $34(13.8)$ & $13(34.2)$ & $21(10.1)$ & $<0.001$ & 4.63 & $2.06-10.38$ \\
\hline Total & $61(24.8)$ & $14(36.8)$ & $47(22.6)$ & Ns & 1.99 & $0.95-4.16$ \\
\hline \multicolumn{7}{|l|}{ Zygomatic fr. } \\
\hline Isolated & $11(4.5)$ & $0(0)$ & $11(5.3)$ & Ns & 0.83 & $0.79-0.88$ \\
\hline Complex with zygomatic fr. & $58(23.5)$ & $13(34.2)$ & $45(21.6)$ & Ns & 1.88 & $0.89-3.97$ \\
\hline Total & $69(28.0)$ & $13(34.2)$ & $56(26.9)$ & Ns & 1.41 & $0.67-2.94$ \\
\hline \multicolumn{7}{|l|}{ Frontal bone fr. } \\
\hline Isolated & $10(4.1)$ & $2(5.2)$ & $8(3.8)$ & $\mathrm{Ns}$ & 1.38 & $0.28-6.80$ \\
\hline Complex with frontal bone fr. & $21(8.5)$ & $11(29.0)$ & $10(4.8)$ & $<0.001$ & 8.06 & $3.13-20.77$ \\
\hline Total & $31(12.6)$ & $13(34.2)$ & $18(8.6)$ & $<0.001$ & 5.48 & $2-40-12.51$ \\
\hline \multicolumn{7}{|l|}{ Lower orbital rim fr. } \\
\hline Isolated & $2(0.8)$ & $1(2.6)$ & $1(0.5)$ & Ns & 5.59 & $0.34-91.43$ \\
\hline Complex with orbital lower rim fr. & $59(23.9)$ & $8(21.0)$ & $51(24.5)$ & Ns & 0.82 & $0.35-1.90$ \\
\hline Total & $61(24.7)$ & $9(23.6)$ & $52(25.0)$ & Ns & 0.93 & $0.41-2.09$ \\
\hline Isolated facial bone fr. & $107(43.5)$ & $8(21.0)$ & $99(47.6)$ & 0.002 & 0.29 & $0.12-0.67$ \\
\hline Multiple facial bone fr. & $121(49.1)$ & $29(76.3)$ & $92(44.2)$ & $<0.001$ & 4.06 & $1.83-9.00$ \\
\hline Exitus & $5(2.03)$ & $5(17.8)$ & $0(0)$ & $<0.001$ & 0.13 & $0.10-0.18$ \\
\hline
\end{tabular}

fr.: Fracture; MFT: Maxillofacial trauma; STT: Soft tissue trauma. 
dence analysis, while a very close relationship was found between mandible fracture, frontal sinus fracture and head trauma, these categories were in close association with nasal fracture, maxillary fracture and multiple facial bone fracture by taking part in the same component (Fig. 2).

\section{Glasgow Coma Scale}

Head injury was detected in all of the seven patients with GCS score of 3-8. Head injury was observed in 17 of $19(89.5 \%)$ patients with GCS score of $9-12$. The risk of head injury increased significantly in both groups ( $p<0.001$ for both). Head injury could not be detected in $93.6 \%$ of the patients with GCS score of $13-15(\mathrm{p}<0.001)$.

\section{Mortality Rate}

Only five $(2.03 \%)$ of the 246 patients included in the study died. While all of the patients who died had head injury, the GCS scores of all were 3-8. All of the patients who died also had multiple facial fractures. Thoracic injury accompanying maxillofacial trauma was present in two of the five patients.

\section{DISCUSSION}

Maxillofacial traumas are common traumas encountered in the emergency rooms, and a male predominance is usually seen. The male/female ratio is around 3/1 in the literature. ${ }^{[12-17]}$ Nevertheless, the mean age of the patients exposed to maxillofacial trauma is above 30 years..$^{[3,8,14-19]}$ There is a close relationship between the presence of accompanying head injury in patients with maxillofacial fractures. ${ }^{[2-7]}$ The risk of experiencing head trauma varies between $2.04 \%$ and $14 \% .^{[2,4-7]}$ Patients with head trauma may be divided into those with intracranial hemorrhage, brain contusion and skull fracture. Hohlrieder et al. ${ }^{[15]}$ and Kanno et al. ${ }^{[18]}$ evaluated only the patients with intracranial hemorrhage among those with maxillofacial trauma, and found the rates of intracranial hemorrhage as $9.7 \%$ and $9.0 \%$, respectively. This rate is $3.65 \%(9 / 246)$ in the current study. However, skull fractures and contusions can be as life-threatening as intracranial hemorrhage. Therefore, the assessment of all head traumas accompanying maxillofacial trauma is crucial in terms of understanding the injury that external powers could create in the face along with facial fracture. Hence, all patients with head injury accompanying maxillofacial trauma were evaluated, and the risk of experiencing head injury was found as $15.44 \%$ (38/246) among patients included in the study. This rate is slightly higher than that of similar studies in the literature. The reason for this may be the fact that $61 \%$ of the cases were exposed to high-energy traumas like traffic accident, falls or gunshot injury.

The etiology of maxillofacial trauma may vary between countries. While motor vehicle accident is the leading etiology in most of the studies in the literature, ${ }^{[1,6,13,14,16,18-21]}$ there are also studies available reporting that sports injuries ${ }^{[8,15]}$ or assaults ${ }^{[2,3]}$ are the most common etiologies in maxillofacial trauma. In many studies, while the risk of head trauma accompanying facial fractures has been reported to increase significantly, ${ }^{[8,16,18,22]}$

Hohlrieder et al. ${ }^{[17]}$ reported that traffic accidents did not increase the risk of intracranial hemorrhage in 2195 patients with facial fractures. Kloss et al. ${ }^{[8]}$ found that assaults also increased the risk of intracranial hemorrhages accompanying maxillofacial trauma as well as traffic accidents. Nevertheless, there were no findings about trauma etiologies that significantly increased the risk of head traumas accompanying maxillofacial fracture. The summer season is risky in terms of maxillofacial trauma frequency. ${ }^{[13,16]}$ In this study, patients with maxillofacial traumas were found to present to the emergency room most frequently in the
Fig. 2. Interrelation of categories in multiple correspondence analysis graph. While a close relationship was determined between categories 2, 4 and 10 and categories 6 , 8 and 12 , the categories $2,4,6,8,10$, and 12 are interrelated because of their location in the same area according to the first component (Names of the categories are given in the table next to the graph).

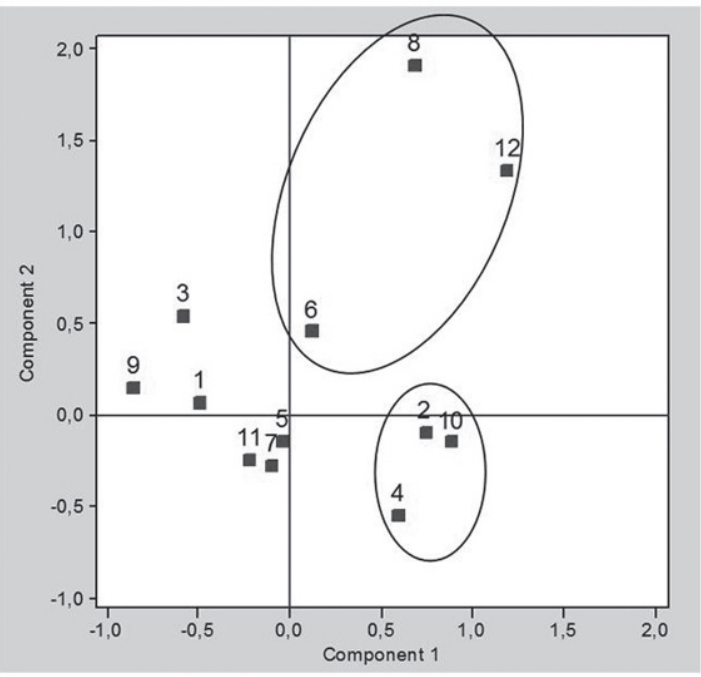

Category no

Nasal fracture

Maxilla fracture

Mandibular fracture

Frontal fracture

Multiple fracture

Head injury 
summer. However, there is no significant relationship between the seasons and experiencing head trauma.

Facial injury should always be of clinical concern with associated brain damage, because it can be a marker for substantial transfer of energy to the brain..$^{[15]}$ GCS is a good marker for determining potential brain injury, clinical conditions and prognosis of the patients following trauma. ${ }^{[10,22]}$ In the current study, the risk of head trauma and mortality rate increased as the GCS decreased. However, this does not mean that there is no risk of head trauma in patients with maxillofacial trauma and high GCS scores. Borzcuk et al. ${ }^{[23]}$ detected abnormal computed tomography (CT) findings in 119 out of 1448 patients who had mild head injury and GCS scores of 13-15, and intracranial hemorrhage required neurosurgical intervention in 11 patients. Kloos et al. ${ }^{[8]}$ reported that intracranial hemorrhage had been detected in $54(2.8 \%)$ out of 1959 patients with maxillofacial fractures and GCS score of 15 . In the current study, head injury was detected in $14(6.36 \%)$ out of 220 patients with GCS scores of 13-15. This leads to the question of the exact relationship between the risk of head injury and location of facial bone fractures independent of GCS and the other clinical findings suggesting head injury. While Kanno et al. ${ }^{[18]}$ did not detect an increase in the risk of intracranial hemorrhage in isolated and simple zygomatic, maxillary and mandibular fractures, they found a significant increase in the intracranial hemorrhage risk in isolated maxillary alveolar fractures and panfacial fractures. On the other hand, Hohlrieser et al. ${ }^{[17]}$ detected that the risk of head injury increased with maxillary fractures. On the contrary, Kloss et al. ${ }^{[8]}$ reported that the risk of head injury significantly increased in all facial fractures except maxillary fractures in their study carried out in patients with GCS score of 15 . However, they did not classify these fractures as isolated or complex. As a result of analysis of 4786 patients with craniomaxillofacial fractures, Mithani et al. ${ }^{[14]}$ found an increase in the risk of head injury in fractures of the upper third of the face and bilateral mandibular fractures. In our study, while the risk of head injury did not increase in isolated single site fractures, the risk of head injury was found to increase in cases with two or more fractures, multiple facial fractures including nasal, maxillary, frontal sinus, and mandibular bone, and in all facial fractures involving the frontal sinus (isolated and complex frontal sinus fractures).

In conclusion, maxillofacial fractures are usually repaired easily by a maxillofacial surgeon, and a lifethreatening risk due to facial fracture alone is usually not present. However, there is a life-threatening condition in cases with head injury accompanying maxillofacial fracture, and making an accurate diagnosis with proper consultations may be life-saving. Among these patients, while the risk of head injury increases in those with multiple facial fractures, this risk does not increase in facial fractures isolated to a single region. Furthermore, even with a GCS of 15 and no clinical findings indicating head injury, head injury may be suspected in patients with multiple facial fractures.

\section{REFERENCES}

1. Follmar KE, Debruijn M, Baccarani A, Bruno AD, Mukundan S, Erdmann D, et al. Concomitant injuries in patients with panfacial fractures. J Trauma 2007;63:831-5.

2. Lim LH, Lam LK, Moore MH, Trott JA, David DJ. Associated injuries in facial fractures: review of 839 patients. Br J Plast Surg 1993;46:635-8.

3. Alvi A, Doherty T, Lewen G. Facial fractures and concomitant injuries in trauma patients. Laryngoscope 2003;113:1026.

4. Mulligan RP, Friedman JA, Mahabir RC. A nationwide review of the associations among cervical spine injuries, head injuries, and facial fractures. J Trauma 2010;68:58792.

5. Tung TC, Tseng WS, Chen CT, Lai JP, Chen YR. Acute lifethreatening injuries in facial fracture patients: a review of 1,025 patients. J Trauma 2000;49:420-4.

6. Brasileiro BF, Passeri LA. Epidemiological analysis of maxillofacial fractures in Brazil: a 5-year prospective study. Oral Surg Oral Med Oral Pathol Oral Radiol Endod 2006;102:2834.

7. Gwyn PP, Carraway JH, Horton CE, Adamson JE, Mladick RA. Facial fractures--associated injuries and complications. Plast Reconstr Surg 1971;47:225-30.

8. Kloss F, Laimer K, Hohlrieder M, Ulmer H, Hackl W, Benzer A, et al. Traumatic intracranial haemorrhage in conscious patients with facial fractures--a review of 1959 cases. J Craniomaxillofac Surg 2008;36:372-7.

9. Mendelow AD, Karmi MZ, Paul KS, Fuller GA, Gillingham FJ. Extradural haematoma: effect of delayed treatment. $\mathrm{Br}$ Med J 1979;1:1240-2.

10. Haug RH, Savage JD, Likavec MJ, Conforti PJ. A review of 100 closed head injuries associated with facial fractures. J Oral Maxillofac Surg 1992;50:218-22.

11. Bouamra O, Wrotchford A, Hollis S, Vail A, Woodford M, Lecky F. Outcome prediction in trauma. Injury 2006;37:10927.

12. Bataineh AB. Etiology and incidence of maxillofacial fractures in the north of Jordan. Oral Surg Oral Med Oral Pathol Oral Radiol Endod 1998;86:31-5.

13. Ferreira PC, Amarante JM, Silva PN, Rodrigues JM, Choupina MP, Silva AC, et al. Retrospective study of 1251 maxillofacial fractures in children and adolescents. Plast Reconstr Surg 2005;115:1500-8.

14. Mithani SK, St-Hilaire H, Brooke BS, Smith IM, Bluebond-Langner R, Rodriguez ED. Predictable patterns of intracranial and cervical spine injury in craniomaxillofacial trauma: analysis of 4786 patients. Plast Reconstr Surg 2009; 123:1293-301.

15. Hohlrieder M, Hinterhoelzl J, Ulmer H, Hackl W, Schmutzhard E, Gassner R. Maxillofacial fractures masking traumatic intracranial hemorrhages. Int J Oral Maxillofac Surg 2004;33:389-95.

16. Hogg NJ, Stewart TC, Armstrong JE, Girotti MJ. Epidemiology of maxillofacial injuries at trauma hospitals in Ontario, Canada, between 1992 and 1997. J Trauma 
2000;49:425-32.

17. Hohlrieder M, Hinterhoelzl J, Ulmer H, Lang C, Hackl W, Kampfl A, et al. Traumatic intracranial hemorrhages in facial fracture patients: review of 2,195 patients. Intensive Care Med 2003;29:1095-100.

18. Kanno T, Mitsugi M, Furuki Y, Fujioka M, Katsumata A, Matsumoto $\mathrm{Y}$, et al. Traumatic intracranial hemorrhages in patients with maxillofacial / jaw fractures. JJAAM 2008;19:1023-8.

19. Sinclair D, Schwartz M, Gruss J, McLellan B. A retrospective review of the relationship between facial fractures, head injuries, and cervical spine injuries. J Emerg Med 1988;6:10912.
20. Imahara SD, Hopper RA, Wang J, Rivara FP, Klein MB. Patterns and outcomes of pediatric facial fractures in the United States: a survey of the National Trauma Data Bank. J Am Coll Surg 2008;207:710-6.

21. Haug RH, Foss J. Maxillofacial injuries in the pediatric patient. Oral Surg Oral Med Oral Pathol Oral Radiol Endod 2000;90:126-34.

22. Keenan HT, Brundage SI, Thompson DC, Maier RV, Rivara FP. Does the face protect the brain? A case-control study of traumatic brain injury and facial fractures. Arch Surg 1999;134:14-7.

23. Borczuk P. Predictors of intracranial injury in patients with mild head trauma. Ann Emerg Med 1995;25:731-6. 